\title{
RURAL ARCHITECTURAL AND PLANNING FORMS AS A SOURCE OF DIVERSITY FOR URBAN ENVIRONMENT (CASE STUDY OF MOSCOW)
}

\section{Alexander Savchenko ${ }^{1}$, Tatiana Borodina ${ }^{2}$}

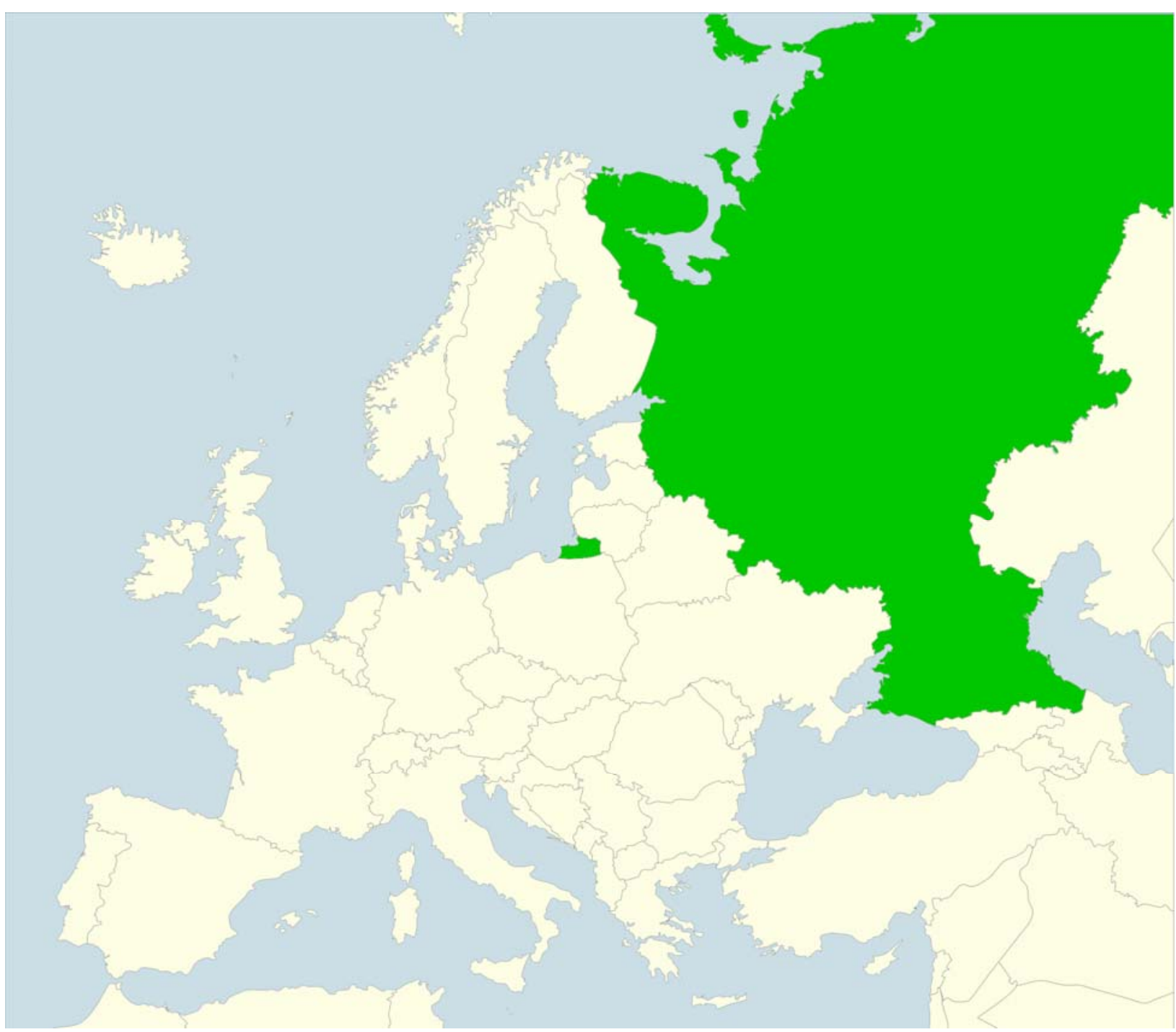

\footnotetext{
1 Prof. Alexander Savchenko, Director of Center for Situational Monitoring and Regional Studies, The Russian Presidential Academy of National Economy and Public Administration, 82/5, Prospect Vernadskogo, 119571 Moscow, Russian Federation.E mail: savchenko_alex@mail.ru

2 Dr. Tatiana Borodina, Senior Researcher, Institute of Geography Russian Academy of Sciences, Staromonetniy Pereulok, 29, 119017 Moscow, Russian Federation. E mail: borodina_tl@mail.ru
} 


\begin{abstract}
Inclusion of specific rural architectural and planning forms in the urban structure of Moscow is analysed. As a theoretical background, theories of Garden-Cities (Howard, 1902), Rural-urban continuum (Sorokin, Zimmerman, 1929), Slow city (Mayer, Knox, 2009) are considered. Inclusion of rural architectural and planning forms is analysed for different structural elements of Moscow's urban environment - public spaces, industrial areas, residential areas, street and road network. Authors argue that once included into the structure of the city, rural planning and architectural forms do not disappear, but after the termination of the implementation of their parent species and ways of life, which are really related to agriculture and other "non-urban" activities, they are transformed for integration into urban life and the environment, contributing to an increase in their diversity. This pattern can be traced consistently, at least, from the XVIII century.
\end{abstract}

Key words: rural architectural and planning forms, urban planning structure, urban development, urban environment, public spaces, industrial areas, residential areas, street and road network, Moscow.

\begin{abstract}
Аннотация: На примере Москвы в статье анализируется включение сельских архитектурно-планировочных форм В городскую среду. В качестве теоретической базы проводится анализ теорий «Города-сада» Э Говарда (Howard,1902), «Сельско-городского континуума» (Sorokin, Zimmerman, 1929), «Медленного города» (Mayer, Knox, 2009). Включение сельских фрорм анализируется для различных структурных элементов городской среды Москвы - общественных пространств, производственных территорий, селитебных территорий, улично-дорожной сети. Делается вывод, что, однажды сложившись в структуре города, сельские архитектурные и планировочные фрормы не исчезают, но после прекращения реализации породивших их видов и способов деятельности, реально связанных сельским хозяйством и другими «негородскими» видами деятельности, они трансформируются для интеграции в городскую жизнь и среду, способствуя увеличению их разнообразия. Эта закономерность устойчиво прослеживается, по крайней мере, с XVIII века.
\end{abstract}

Ключевые слова: сельские архитектурно-планировочные фрормы, городская планировочная структура, городское развитие, городская среда, общественные пространства, производственные территории, селитебные территории, уличнодорожная сеть, Москва.

\title{
1. Introduction
}

The city and the countryside, on the one hand, are the opposite phenomenon, but, on the other hand, it is often very difficult to know where the countryside ends and the city begins. City is relatively a large and permanent settlement, with central functions, and has a particular administrative, legal or historical status based on national laws. Modern states normally use two methods to define their cities - statistical and/or legal. An urban environment is characterised by high density of population and urban amenities (services, institutions, etc.) and by vast human features. Most of the living and working spaces, shopping areas, educational facilities, public services etc. are grouped in close proximity to each other. It is usually characterised by limited open areas (green spaces) in specifically planned urban zones or places abandoned by dwellers owing to the higher value of real estate (Brade, Kovacs, 2014). Any city in the process of its growth absorbs the surrounding countryside. Part of it disappears forever, but many of its elements are preserved, fitting into the urban environment. With the increasing mobility of the population and the emergence of many transitional forms between urban and rural areas 
due to processes of urbanisation, suburbanisation, desurbanisation, re-urbanisation etc. it is difficult to make a clear distinction between urban and rural areas. Our research objective of this paper is to test how the use of rural architectural and planning forms, rural built environment and spatial planning supports not only as a result of the current projects, but also for long-term transformational trends, cultural identity and environmental diversity even in global cities, such as Moscow.

\section{Theoretical background}

In the process of urbanisation, there is the growth of cities and the spread of urban way of life into the countryside. But at the same time, we can see increasing desire of urban residents for nature in the form of tourism, recreation, agro-recreational (gardening and "dacha") possessions and occupations. Ideas how to save the advantages of the rural way of life in an urban environment existed at various times. In 1902, British urban planner E. Howard published a book "Garden Cities of To-morrow", that gave rise to the garden city movement (Howard, 1902). This book offered a vision of towns free of slums and enjoying the benefits of both town (such as opportunity, amusement and high wages) and country (such as beauty, fresh air and low rents). Garden cities were intended to be planned, self-contained communities surrounded by "greenbelts", containing proportionate areas of residences, industry, and agriculture. Howard's ideas were laid into the basis for regional policy and creation of new cities in different European countries after the World War II, including the Soviet Union, especially for regulating the development of the major metropolitan cities and agglomerations.

In the 1920s, American sociologists P. Sorokin and C. Zimmerman put forward the idea of Rural-urban continuum (Sorokin, Zimmerman, 1929). Rural-urban continuum, the merging of town and country, a term used in the recognition of the fact that in general, there is rarely, either physically or socially, a sharp division, a clearly marked boundary between the two, with one part of the population wholly urban and the other wholly rural .

And R. Redfield found an example of folk-urban continuum in one Mexican community, a concept relating to the transition from rural to urban societies. Investigation of the social, cultural, and economic characteristics of individual societies allows them to be positioned at different points along an evolutionary path (Redfield, 1930).

The term rural-urban continuum came into existence because of the fact that a marked difference between the urban and rural character is not seen in the settlements abutting the city limits. On one hand, they have characteristics of the city because of their closeness to it and on the other hand, they cannot deny their rural characteristics of largely unplanned development.

Some economists and sociologists have used the concept of rural-urban continuum to stress the idea that there are no sharp breaking points to be found in the degree or quantity of rural urban differences. The differences may arise due to various factors. But the leading factor among them is migration. Although, the rapid process of urbanisation through the establishment of industries, urban traits and facilities has decreased the differences between villages and cities, yet this continuum or loss of demarcation has proven problematic to planners and other civic departments because these areas being near the city facilitate movement of people in and out of the city, and hence demand extension of facilities. This is where the entire problem lies. These areas have been of substratum for immense research in the past centuries with eminent sociologists, planners and others inferring as well as proposing ways to tackle this problem of fringe area development (Dewey R., 1960; World Development Report, 2009). In most parts of Europe, the difference between urban and rural areas is gradually disappearing, and large tracts are turning into dispersed urban-rural landscapes as observed by the British architectural critic D. Sudjic (Sudjic, 1993). His analysis concentrated on the world cities of New York, Los Angeles, Tokyo, Paris and London. He examined what makes a city a city? Sudjic wrote about how cities grow and change through their buildings and how people live and work in them and writes a devastatingly graphic portrait of the phenomenon emerging from the 1980s: standardised, monolithic, corporate urban sprawls that are the outward expression of a new society, a blueprint that will affect the lives of tens of millions of people. Some authors, for 
example L. Niström, (Niström, 1995) analysed the rural-urban continuum and the diversity of the urban environment from the position of the Postmodernism and the diversity of lifestyles. A. Treivish developed the continuum typology by Russia's regions (Treivish, 2016).

But at the end of the XX century, however, people and places, both rural and urban, have been confronted with change on an unprecedented scale and at an extraordinary rate. Economic and cultural globalisation have resulted in a "network society" dominated by flows of capital, ideas, and people (Castells, 1996). Globalisation has generated a world of restless landscapes in which the more places change, the more they seem to look alike and the less they are able to retain a distinctive sense of place. Non-existent earlier transnational material culture evolved around the consumption of globally branded products. Another outcome of globalisation is the trend towards homogenisation. Through increased connectedness, communities are losing their distinctive characteristics because global habits are spreading. One example of this diffusion is the proliferation of fast food places. The global spread of foodstuff threatens local producers and consumers, as well as traditions developed around food production and consumption. The Slow City movement represents immediate action against such "McDonaldisation" of society (Ritzer, 2004) and represents a resistance to the increased pace of life and "placelessness" (Mayer, Knox, 2009). We can consider The Slow City movement as unexpected and paradoxical expression of rural-urban continuum.

The Slow City movement (Italian "Cittaslow") began in 1999 in Italy. The goal is to foster the development of places that enjoy a robust vitality based on good food, healthy environments, sustainable economies, and traditional rhythms of community life (Slow cities, 2017; Cittaslow, 2017).

These ideas soon led to a Charter and a 54-point indicator system that leans heavily towards the fostering of conviviality and the promotion of high-quality local produce. Community quality-of-life indicator system covering six key areas: environmental policies and planning; the use of infrastructure; integration of technology; promotion of local produce and ways of life; hospitality and the rhythm of life; and sense of place. Each national network of member towns, and each individual town, must develop a set of indicators based on the Charter (Mayer, Knox, 2009).

Cities of "Cittaslow" movement from different European countries often decide problems of local rural landscape protecting, local agriculture and forestry, as well as local products and trade, and local cuisine. Ultimately, it is the protection and development of the built environment and spatial planning in local rural areas, local rural architecture and planning forms (Knox, P. 2005).

Quality-of-life and sustainability indicators similar to the Slow City system have become commonplace. In North America, examples include Sustainable Seattle and Sustainable Calgary (Keough, 2005). These projects are characterised by a high level of citizen engagement through an extensive public participation process. Similar to the Slow City charter, they assess the economic, social, and environmental well-being of a community. In the case of Calgary, citizens were asked which initiatives would have a significant and positive impact on the sustainability of the community. They expressed interest in improving the community's sense of place, supporting environmental protection, and encouraging a culture of simplicity (Keough, 2005). These priority areas would demand major shifts in lifestyles and the support from urban development policies and programs.

Therefore we can say that the principles of Cittaslow movement may be applied not only to a small city, but also to large and to global centres.

An interesting variant of the approach to understanding the big city as a result of inconsistent interaction of current architectural projects and the long-term historical evolution is presented by T. Farrell (Farrell, 2014). 


\section{Administrative borders of Moscow}
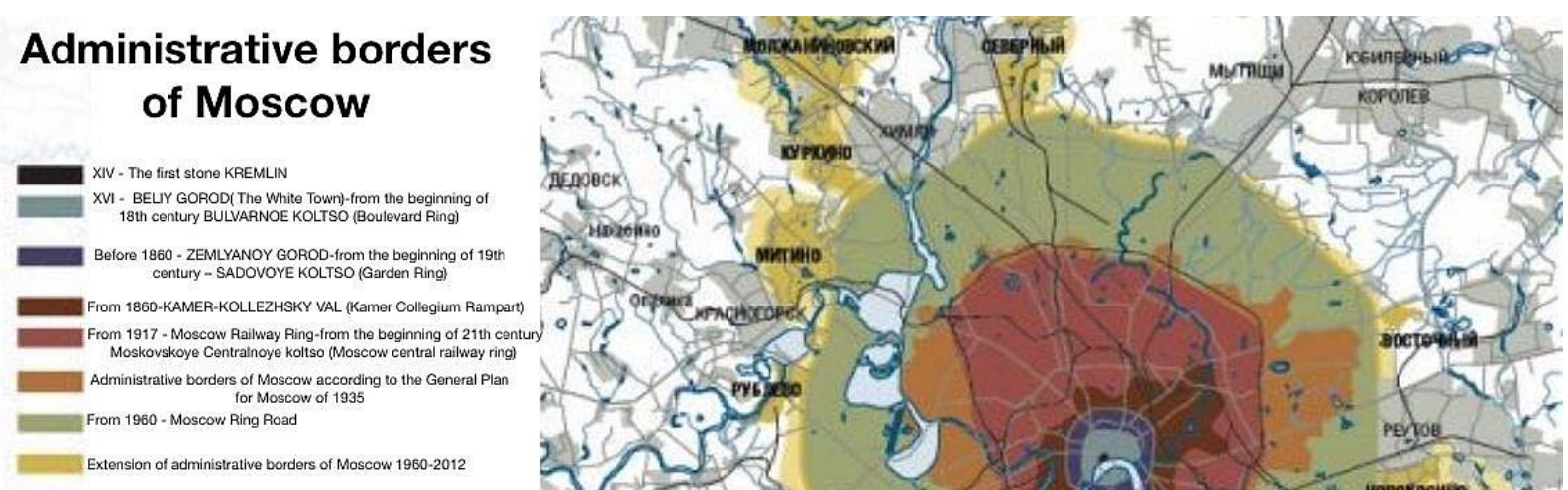

IV Administrave borders of Moscow from 2012

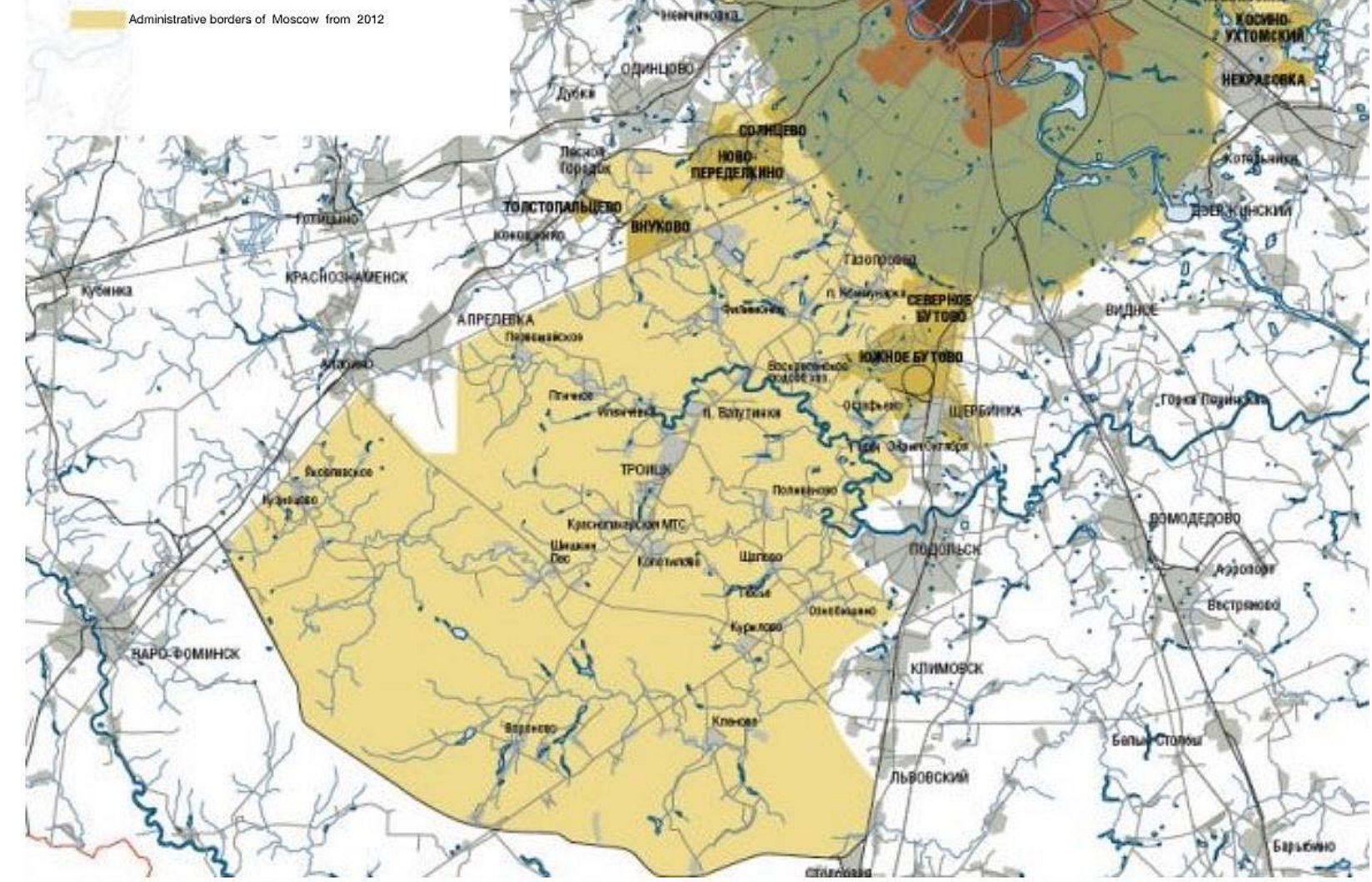

Fig 1. Stages of change in the administrative borders of Moscow. Source: Savchenko, A., ed. (2013)

\section{Methodology and area under study}

Research objectives of this paper was to determine the choice of historical and geographical approach as the main, as well as genetic method in the analysis of the formation of a number of modern forms built environment and spatial planning due to their original rural origin and subsequent transformation in accordance with the changing social demands and economic factors.

Selection of historical and geographical approach as the main method involves choosing monitored period, for which there are cartographic materials, in this case, urban plans.

The full historical series of Moscow plans were analysed, beginning from the very first, from $\mathrm{XVI}$ century. The main evolutionary tendencies are visible in urban plans of Moscow throughout four centuries, also trends and factors of long-term changes of the city spatial structure which set contours of its present. During all four centuries, Moscow grew step by step assimilating rural neighbourhood. But in the last hundred years, these steps became really big (Fig. 1). Growth of population and territory of Moscow are shown on the Table 1 and on Table 2 principal factors of Moscow's spatial structure transformation. 
Tab 1. Population and Territory of Moscow. Source: Savchenko, A., ed. (2013)

\begin{tabular}{|c|c|c|}
\hline Stages & Population, thous. people & Territory, $\mathrm{km}^{2}$ \\
\hline XVII century & $>150$ & \multirow{4}{*}{19.7} \\
\hline 1785 & 180 & \\
\hline 1810 & 260 & \\
\hline 1842 & 350 & \\
\hline 1860 & 360 & \multirow{4}{*}{91.5} \\
\hline 1885 & 800 & \\
\hline 1907 & 1200 & \\
\hline 1910 & 1500 & \\
\hline 1917 & 1800 & 232.9 \\
\hline 1926 & 2100 & \multirow{4}{*}{233} \\
\hline 1933 & 3700 & \\
\hline 1939 & 4100 & \\
\hline 1959 & 5000 & \\
\hline 1960 & 5100 & \multirow{4}{*}{878.7} \\
\hline 1970 & 7100 & \\
\hline 1979 & 8000 & \\
\hline 2007 & 11100 & \\
\hline 2010 & 11500 & 1080 \\
\hline 2012 & 12000 & 2680 \\
\hline
\end{tabular}

Tab 2. Principal factors of Moscow's spatial structure transformation. Source: Savchenko, A., ed. (2013)

\begin{tabular}{|l|l|l|}
\hline Stages & Factor & Results \\
\hline $\begin{array}{l}\text { 16th century - } \\
\text { 17th century }\end{array}$ & Fortification & $\begin{array}{l}\text { Rings of fortifications of the city, Kremlin } \\
\text { (castle), Kitay-gorod (trading quarter), Bely } \\
\text { gorod (White town), Zemlyanoy gorod } \\
\text { (Earthwork town), routes of main roads } \\
\text { providing connections with other cities of Russia }\end{array}$ \\
\hline $\begin{array}{l}\text { 18th century - } \\
\text { the first half of } \\
19 t h \text { century }\end{array}$ & Regular reconstruction & $\begin{array}{l}\text { Ring directions of main city roads and fan radial } \\
\text { streets, diverging from the gates in the city } \\
\text { fortifications }\end{array}$ \\
\hline $\begin{array}{l}\text { 1850-1910 } \\
\text { 1920s - the first } \\
\text { half of 1930s }\end{array}$ & $\begin{array}{l}\text { Forced } \\
\text { industrialisation }\end{array}$ & $\begin{array}{l}\text { An eccentricity of street and road network and } \\
\text { railway network has been formed }\end{array}$ \\
\hline $\begin{array}{l}\text { The second half } \\
\text { of the 1930s }- \\
1950 s\end{array}$ & $\begin{array}{l}\text { There is a region order of industrial territories in } \\
\text { the middle part of the city that is formed: one is } \\
\text { the southeastern district of industrial territories, } \\
\text { and the smaller one is the northwestern district }\end{array}$ \\
\hline reconstruction & $\begin{array}{l}\text { Radial-circular layout of street and road network } \\
\text { in the central part of the city has been reinforced } \\
\text { and the main intercity highways have been } \\
\text { extended, the formation of Moscow metro radial- } \\
\text { circular network has begun }\end{array}$ \\
\hline $1960-1980 s$ & $\begin{array}{l}\text { Results } \\
\text { Prefabricated house } \\
\text { building }\end{array}$ & $\begin{array}{l}\text { Active development of free areas between } \\
\text { Moscow Ring Railway and Moscow Ring Road; }\end{array}$ \\
\hline
\end{tabular}




\begin{tabular}{|l|l|l|}
\hline & & $\begin{array}{l}\text { formation of belts of areas subject to settlement } \\
\text { in the peripheral part of the city between } \\
\text { Moscow Ring Road and the southeastern and } \\
\text { the northwestern belts of industrial areas; } \\
\text { concentration of the capital functions of Moscow } \\
\text { in its middle area, as well as in the South-West, } \\
\text { the West and the North-East of its peripheral } \\
\text { parts }\end{array}$ \\
\hline 1990-2010s & $\begin{array}{l}\text { proliferation of private } \\
\text { cars and post- } \\
\text { industrialisation in } \\
\text { post-socialist } \\
\text { transformation }\end{array}$ & $\begin{array}{l}\text { Spread of ring-radial structure of street and road } \\
\text { network to the medial part of the city (The } 3^{\text {rd }} \\
\text { Transport ring construction). } \\
\text { Transformation from monocentric spatial } \\
\text { organization of the city into the polycentric one }\end{array}$ \\
\hline
\end{tabular}

Inside the Moscow Ring Road a central part of the city nearly into the borders of Kamer Collegium Rampart preserved elements of the historical urban environment. It has the richest potential for relief, and includes a number of its various types: major physical-geographical complexes converge as radii to the Kremlin: Moscow Meshcherskaya lowland (I), Teplostanskaya erosion hill (II) and the southern slope of the Klin-Dmitrov moraine hill (III). Between Kamer Collegium Rampart and the Moscow Ring Road there is a system of park ensembles and a number of preserved buildings of the former suburban family estates of XVIIXIX centuries, often associated with the forest-park zone (Fig. 2).

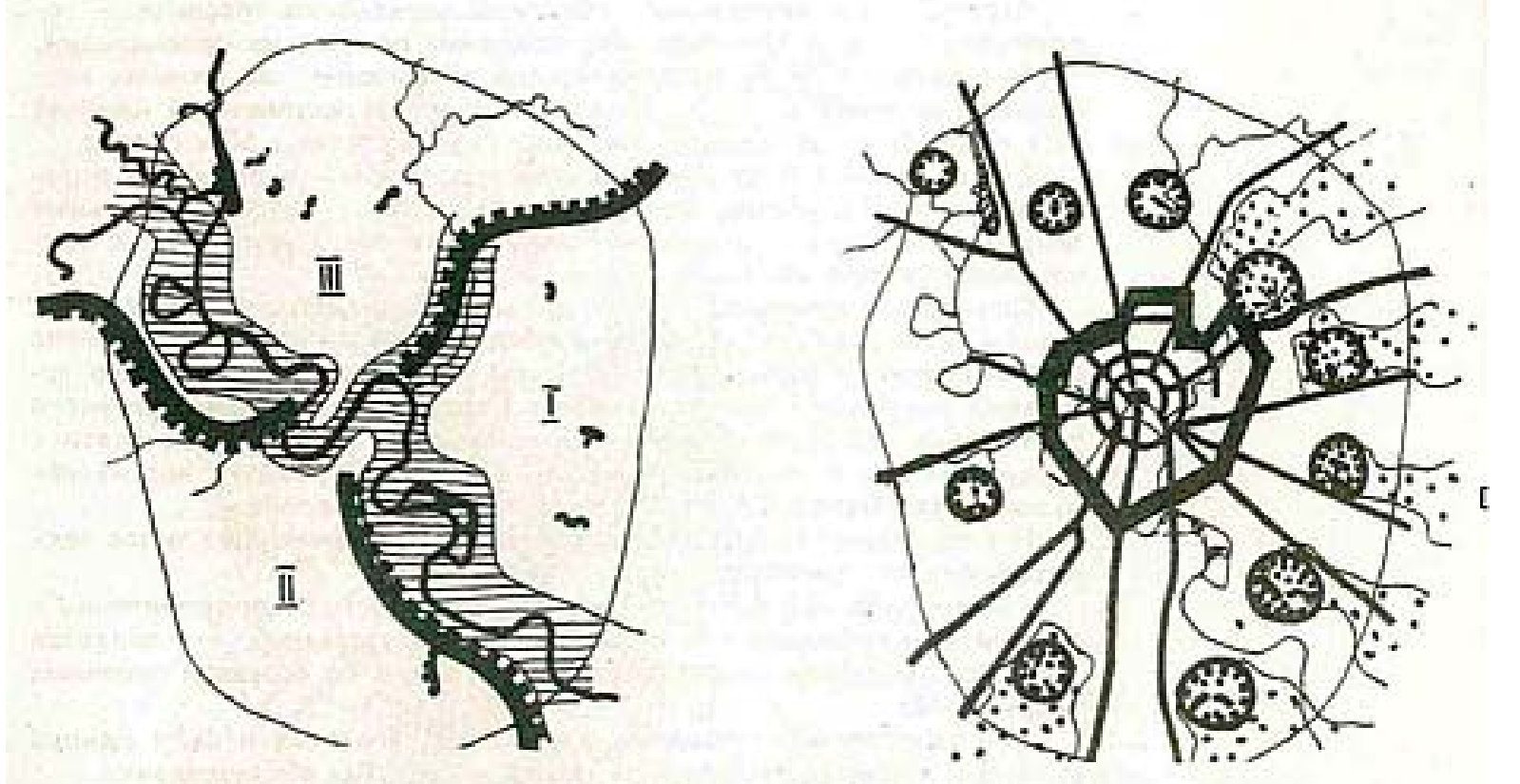

Fig 2. Scheme to identify specific areas in the assessment of natural landscape and historical and architectural characteristics of the city. Source: Savchenko, A., ed. (2013) 


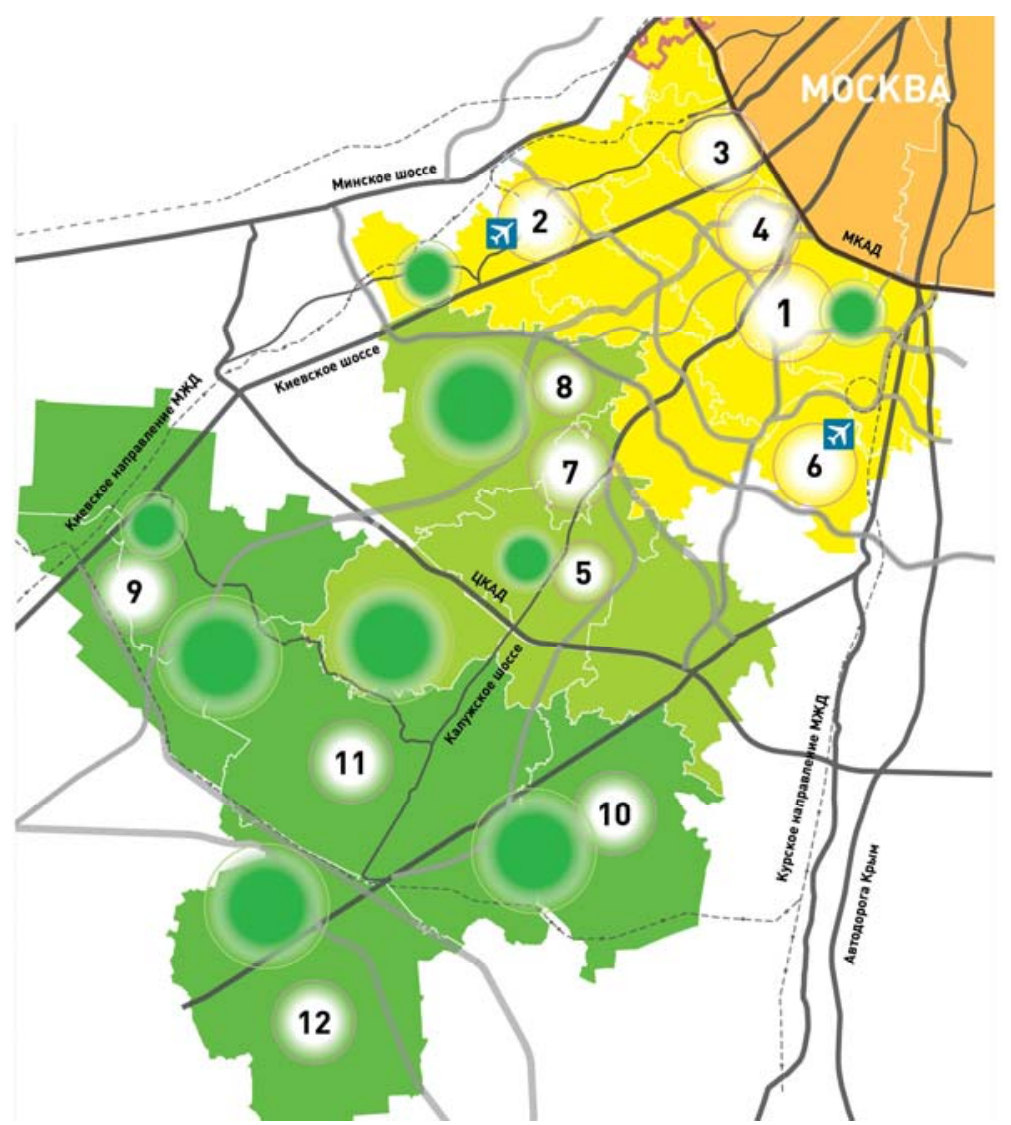

Fig 3. The main directions of the complex urban development of new territories of Moscow. Source: Savchenko, A., ed. (2013)

Figure 3 shows the main directions of the complex urban development of new territories of Moscow. Three belts are planned. The first belt (yellow) is partly an urbanised area with a high concentration of administrative and business buildings (building density is no more than 10 thous. $\mathrm{m}^{2} / \mathrm{ha}$ ). The second belt (light green) is a zone of low urbanisation, with the concentration of education and health institutions (building density is no more than 7 thous. $\mathrm{m}^{2} / \mathrm{ha}$ ). And the third belt is a recreation area with low-rise residential buildings (building density is no more than 5 thous. $\mathrm{m}^{2} / \mathrm{ha}$ ).

\section{Public spaces}

Two of the most famous public spaces in Moscow besides Red Square - Gorky-park and Exhibition of Economic Achievements (ENEA, in Russian VDNH), originally emerged as agricultural exhibition. All-Union Agricultural Exhibition (VSHV) started to build in 1923 and was placed in the centre of the city, on the west intersection of Garden Ring and the Moskva River. Architect Nikolay Markovnikov, who was the main developer of the village Sokol, the only one preserved in Moscow's example of Garden City, was one of the designers of wooden pavilions on this exhibition. By the mid-1930s, there was little space for the exhibition in the centre and according to the Master Plan in 1935, it was moved to the northern outskirts near the Moscow circular railway, near Ostankino, and the place of the first exhibition along the embankment of the Moskva River was reorganised into the Central Park of Culture and Recreation, (Gorkypark). 


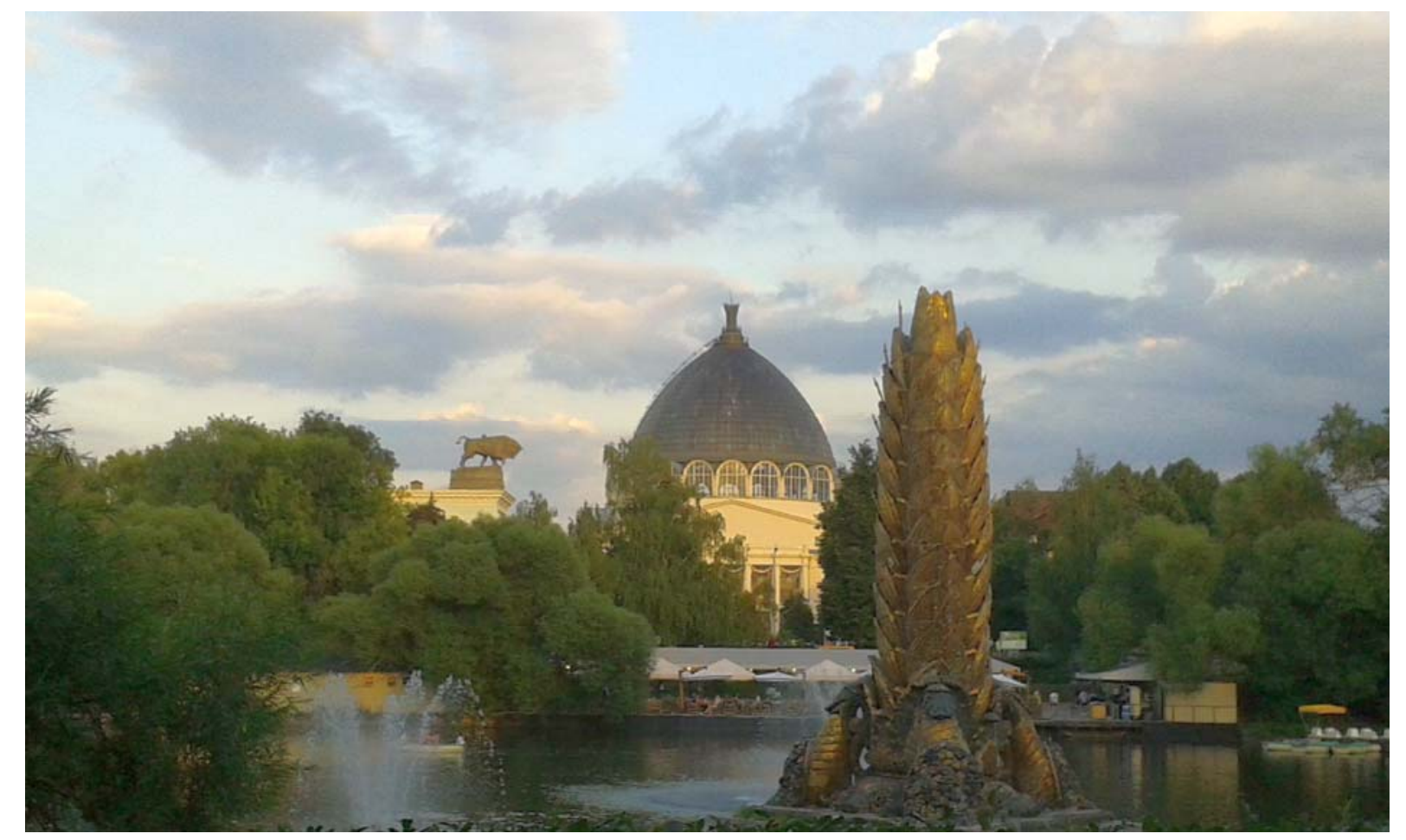

Fig 4. Exhibition of Economic Achievements (VDNH). Photo: Tatiana Borodina, 2016

In 1939, the Agricultural Exhibition was opened at the new location. Since 1959, it became the Exhibition of Economic Achievements (VDNH) and the demonstration of advances in space exploration and other technical subjects became the dominant ones, as well as the exposure of all Soviet republics. However, agriculture was not forgotten. For example, some pavilions were dedicated to winemaking and had "tasting rooms", which continued to be very popular. And until now, the widespread presence of architectural details related to agriculture at the main entrance arch, topped by the figures of Worker and Collective Farm Woman, holding a huge sheaf; a giant statue Worker and Collective Farm Woman, which received Grand Prix in Paris in 1937; fountains and lights in the form of ears; numerous sculptural groups of various genres, including statues of bulls in full size at the front of the huge pavilion, once intended for livestock, are the peculiarities of this place (Fig. 4).

The most common forms of public spaces are formed on the basis of the inherited ensembles of estates and palaces, that are located in the former rural surroundings of the city. Now they have become numerous parks located in different sectors in the middle and peripheral parts of the territory of Moscow. They are more than a dozen, they are cultural and recreational dominants of surrounding areas - Kuskovo in the East, Lublino in the south-east, PokrovskoyeStreshnevo the north-west, Ostankino in the North, etc. Their number is growing as the realisation of plans of restoration, for example, reconstructed ensemble Tsaritsyno in the south of Moscow. In addition to parks, museum complexes are often created in the estates, and also a restored historic agricultural activities. The most famous are the former royal manors Kolomenskoye in the South, Izmailovo in the East and Sheremetev's manor Ostankino in the North. The largest and most significant ensemble (which even has a status of UNESCO heritage) is a royal estate Kolomenskoye on the banks of the Moscow River. In the aspect of this paper theme, it is necessary to note that the historically established gardening (apples and berries for sale) existed on the territory of the estate until the mid-1970s, and the real village Djakovo, which is located on the territory of the museum-reserve, using the conservation status of the surrounding area, survived the Soviet Union and was finally eliminated only during the wave of post-Soviet market reforms. And all this is less than ten kilometres from the Kremlin. Extensive apple orchards are stored in Kolomenskoye now, as well as restored by samples of XVII century apothecary garden, where medicinal plants are cultivated as before. Every year more than five million people visited Kolomenskoye (Fig. 5). 


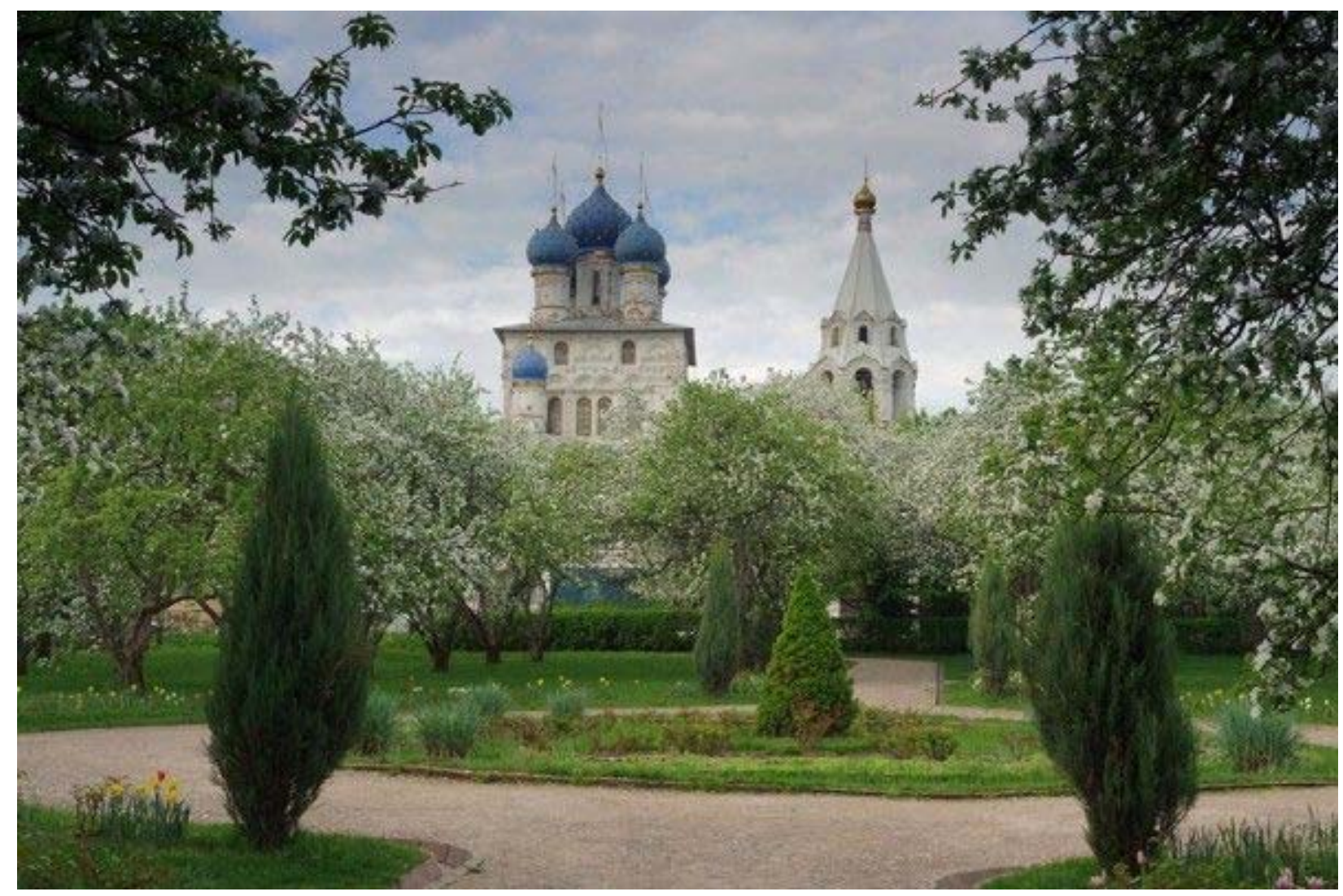

Fig 5. Blooming apple trees in Kolomenskoye.

\section{Industrial areas}

Aptekarskiy ogorod (the Apothecaries' Garden) was founded by Peter the Great in 1706 and he transferred it from the Kremlin walls to the north of the then city fortifications (later they became the Garden Ring, which is now the centre of the city). Peter the Great became the ancestor of a specific type of industrial areas related to agriculture, which are now for research and educational purposes, but at the same time, they are public spaces. The Apothecaries' garden throughout the XVIII century, as expected, was administrated by various medical institutions, but at the beginning of the XIX century, it was transferred to Moscow University for the organisation of the botanical garden. As such, it still exists today as "the Apothecaries' Garden, branch of the Botanical Garden of Moscow State University." He has unique exhibits, including old greenhouses that has existed since the XVIII century, and is open to the public. Currently, the Apothecaries' Garden is very popular and annually it is visited by hundreds of thousands of people (Fig. 6).

In the mid-twentieth century, the area of the botanical gardens of Moscow has increased significantly. In connection with the construction of a new building of the Moscow State University on Vorobievy (then Lenin) Hills in 1950, the main extensive university botanical garden was laid out there, and then today, it specialises in the outdoor botanical collections. But five years ago, in 1945, the Main Botanical Garden of the Academy of sciences of the USSR was founded to the west of the Agricultural Exhibition (now VDNH). Currently, it is the largest botanical garden in Europe. In order to enable the inclusion of the botanical garden into the life of the city, its territory was united with the main territory of VDNH, so the number of visitors increased significantly (up to one million people annually) (Fig. 7). 


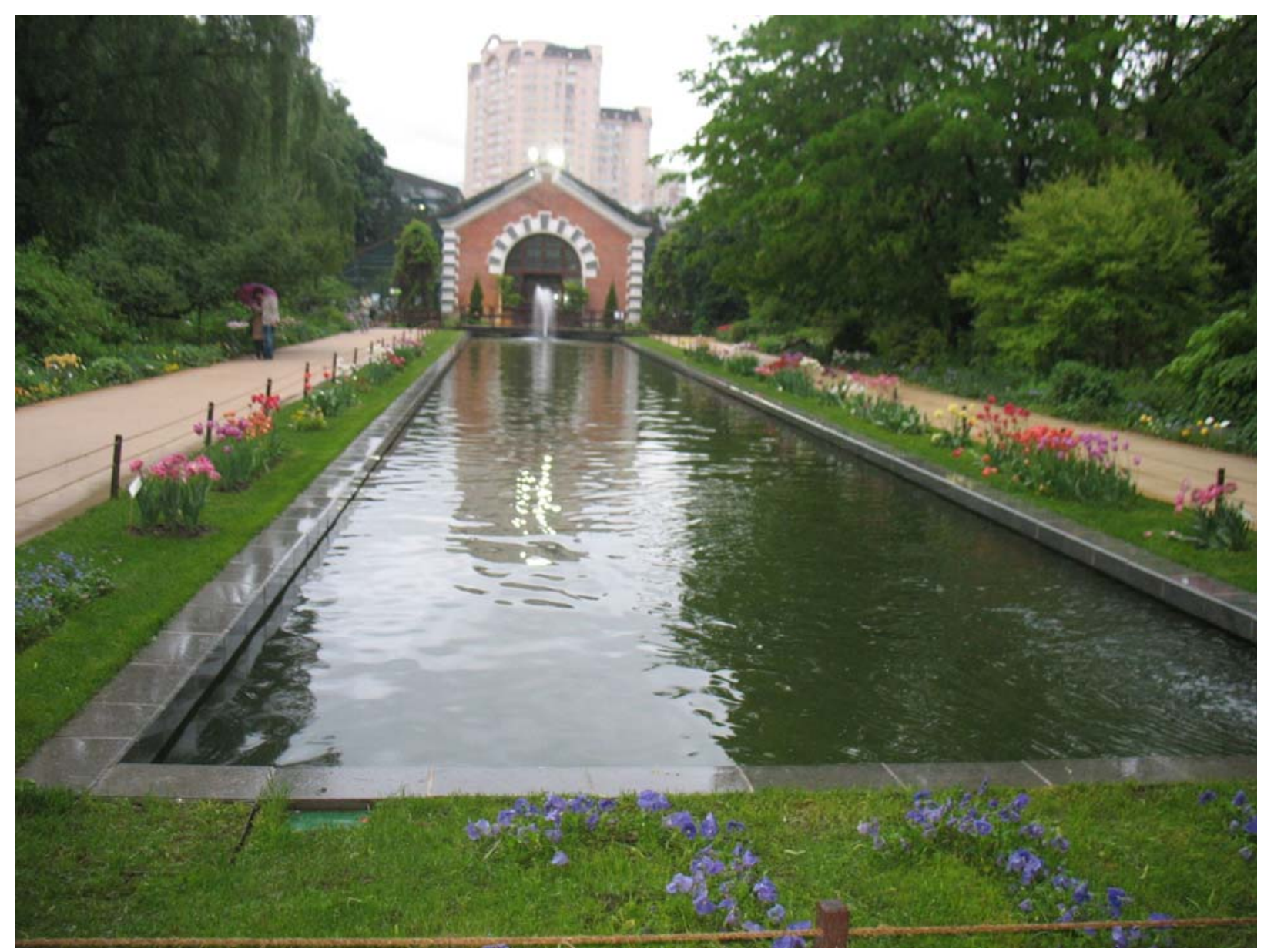

Fig 6. The Apothecaries' Garden. Photo: T. Borodina, 2016

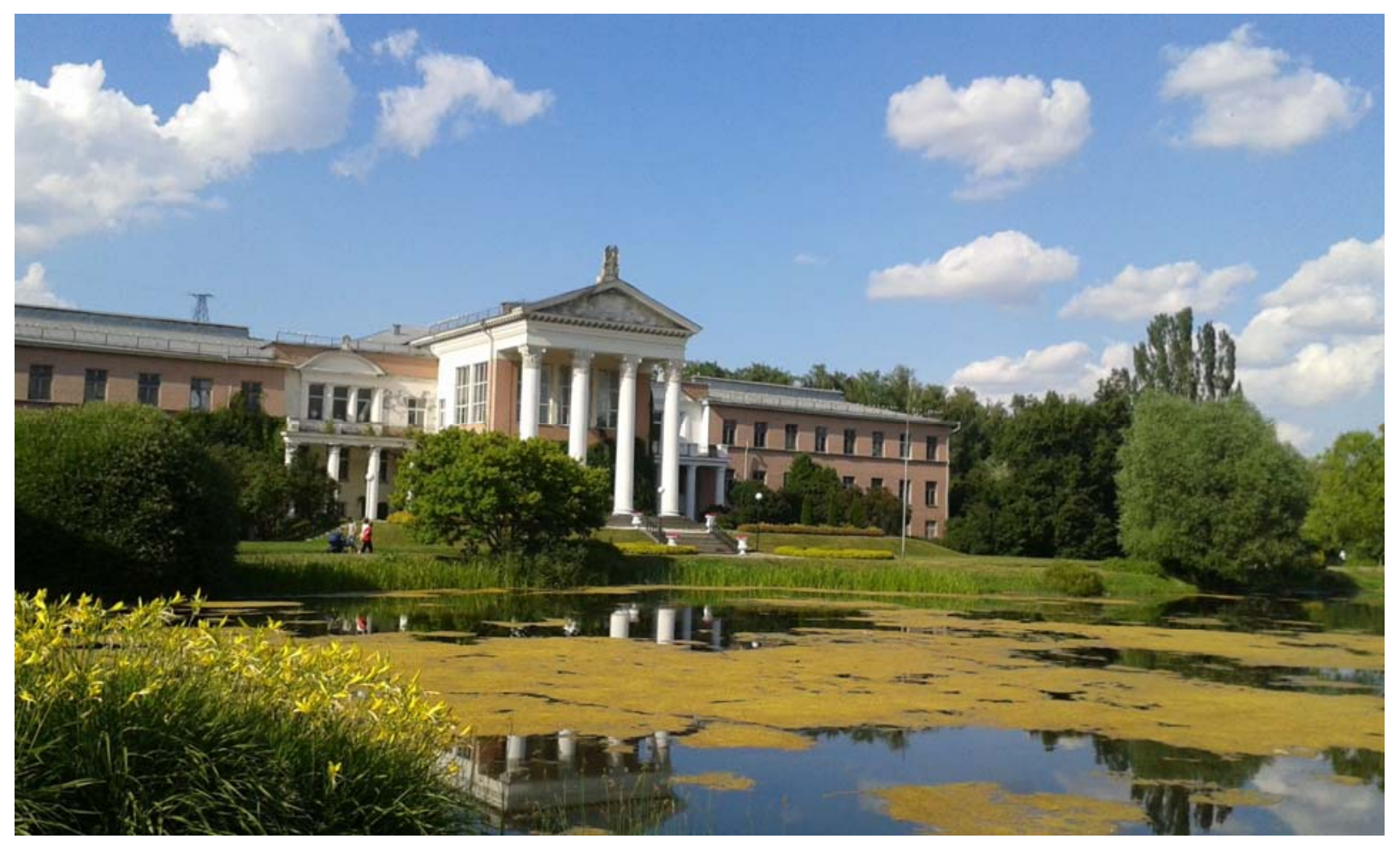

Fig 7. The Main Botanical Garden of the Russian academy of sciences. Photo: T. Borodina, 2016 
We can also see another transitional type of industrial areas related to agriculture. There are extensive experiment farmlands of Moscow Timiryazev Agricultural Academy (now - Russian State Agrarian University). When the Academy was created in the second half of the XIX century, it was far beyond the city border. Now, it is the central area of Moscow, approximately three kilometres to the west of the Main Botanical Garden of the Academy of Sciences, and it is adjacent to the inner part of the Moscow central railway ring, which now has become an inner passenger railway. Agricultural Academy has experiment fields, orchards and seed plots, nursery-gardens, breeding station, a dairy farm, poultry houses and even pond farms (Fig. 8).

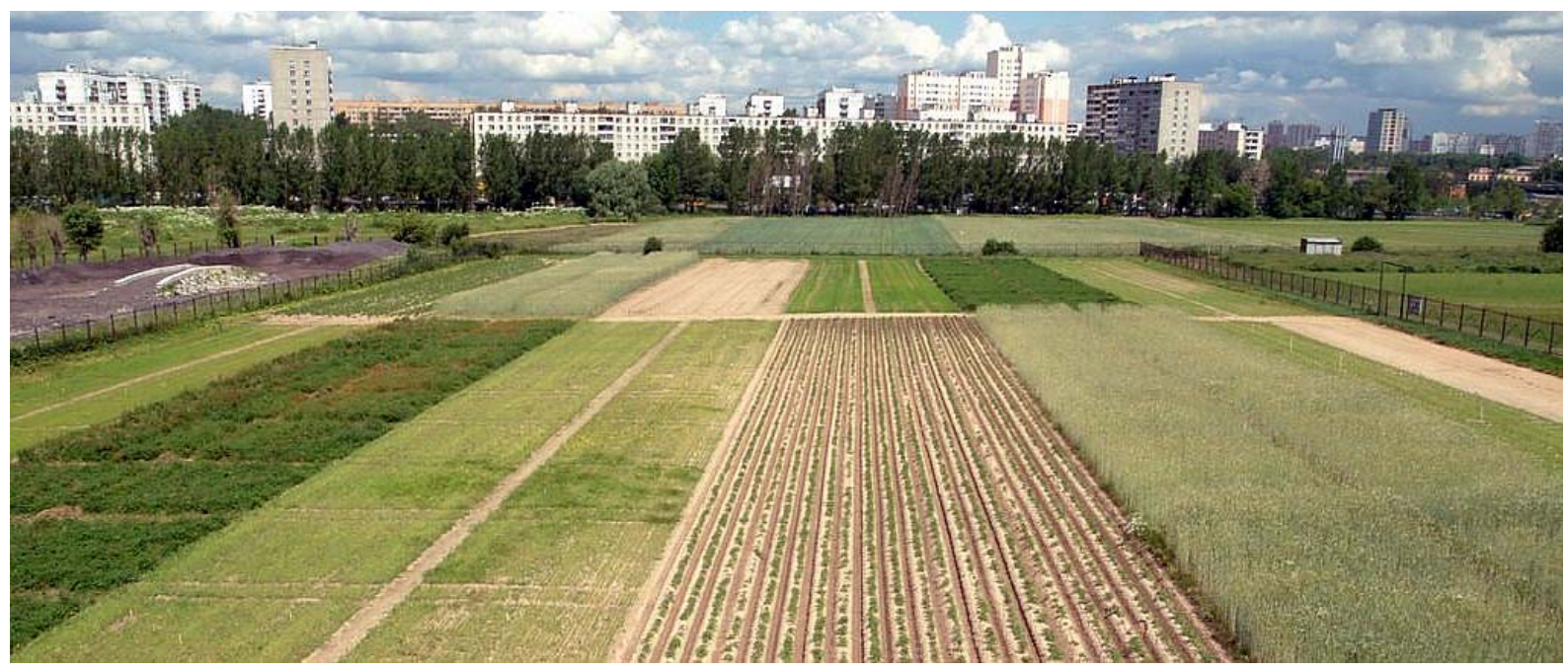

Fig 8. Experiment fields of Russian State Agrarian University.

But in New Moscow, there are real agricultural production areas in close (next to the Moscow Ring Road) and distant (close to the border of the Kaluga region) sectors. Greenhouse production enterprises, such as Moskovskiy and Belaya Dacha, are the main suppliers of salads and greenhouse vegetables for Moscow's supermarkets. Complete agricultural cluster in the farther zone is planned in the draft of territorial planning documents for development inherited from the Moscow oblast agricultural enterprises (Fig. 9).

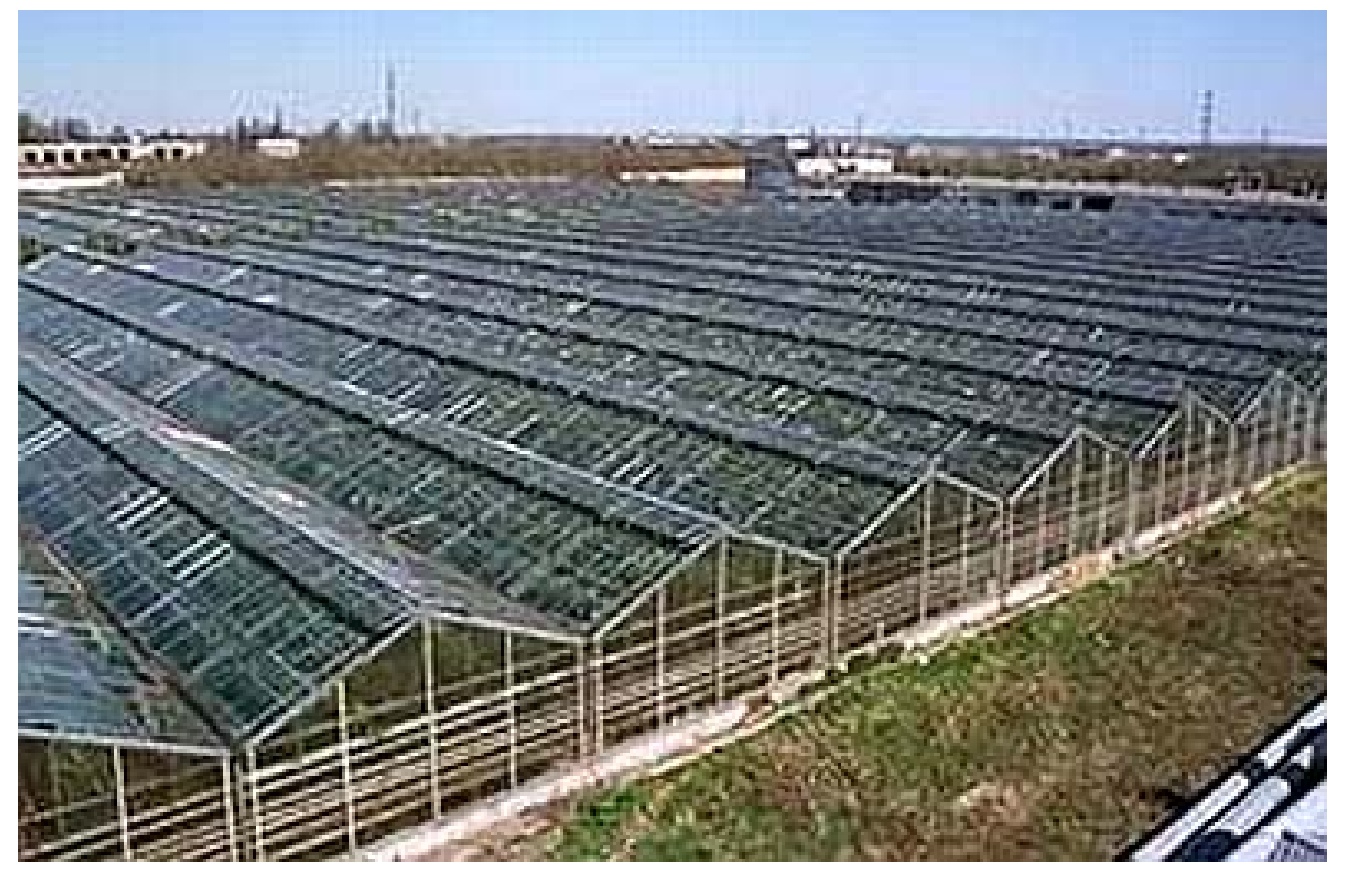

Fig 9. Greenhouses at Belaya Dacha. 


\section{Residential areas}

In the twentieth century, after the first transfer of administrative border of the city and appropriate increase of the urban territory (in two and a half times compared to the original area) up to the Moscow central railway ring in 1917, a question of a large-scale transformation and integration of the rural periphery into the city was raised for the first time. For this goal, the first Soviet master plan of 1923 provided the creation of Garden Cities system in accordance with the contemporary European trend (Howard, 1902). Moreover, there was a prerevolutionary experience in 1909 in the Moscow suburbs. In a 10-kilometre radius from the Yaroslavl and Kursk railway stations, two settlements were built, each for hundreds of homes, implementing the principles of Howard's Garden Cities, Losinoostrovsky and Novogireevo, respectively,(Ul'janova, 2012).

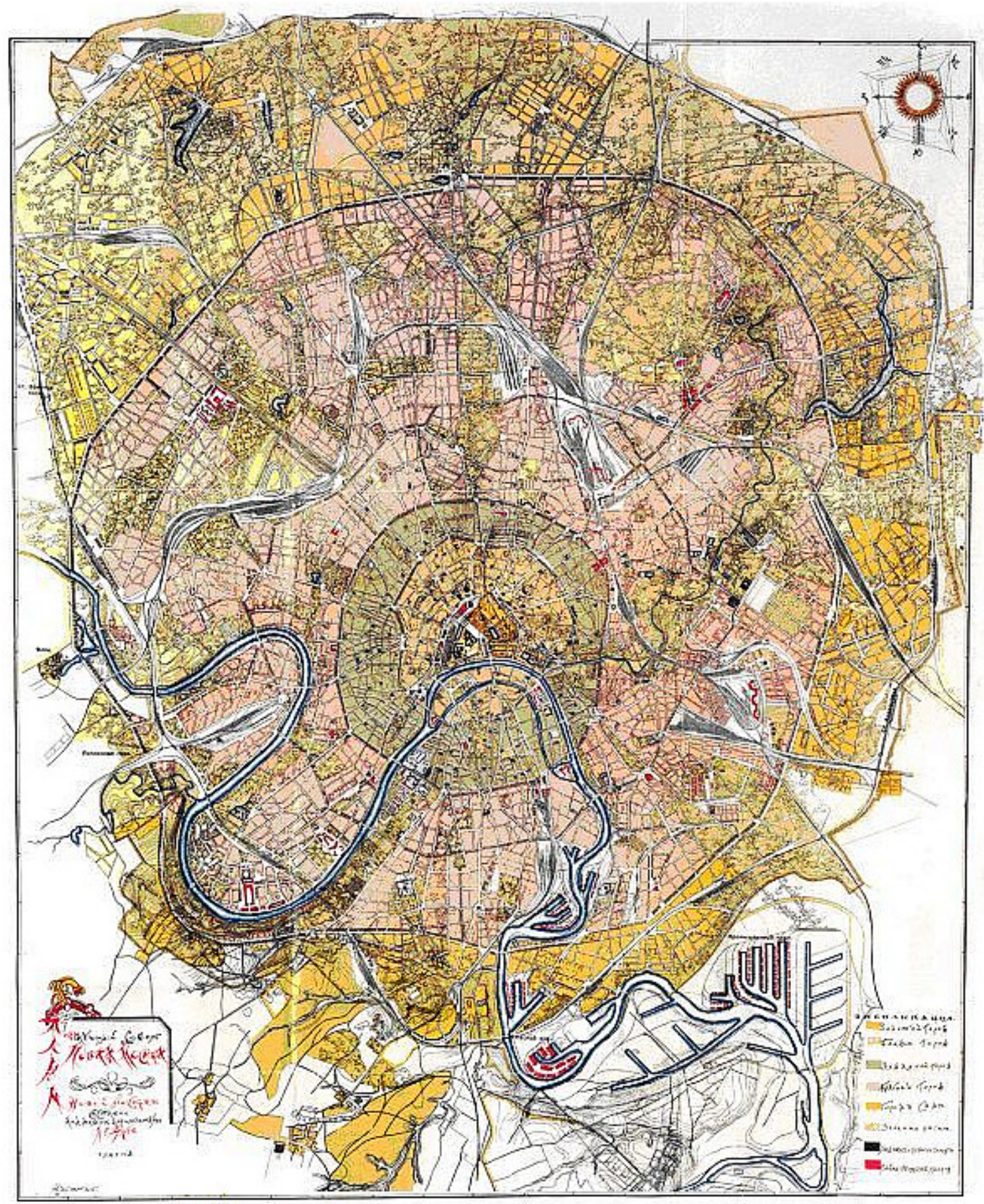

Fig 10. Plan for New Moscow. A. V. Shchusev, Academician of the architecture. Source: Savchenko, A., ed. (2013) 
Unfortunately, they are now lost. Master Plan of 1923 provided decentralised planning structure, further development of the ring highways system, as well as the foundation of the new park ring. It was focused on the maximum respect for the existing city planning structures and to architectural monuments, especially the ancient ones. The Garden Cities system was proposed to form inside of the Moscow central railway ring, primarily covering the vast undeveloped area north of the Kamer-Kollezhsky Val (Kamer Collegium Rampart). Unfortunately, the master plan has not been approved officially, although some of his ideas were used later (Fig. 10). In the transformations of 1930 - 1950, its initiatives were largely forgotten, except one very interesting project. Fortunately, it has almost completely been implemented, and not lost later. It is Garden City Sokol inside the north-western section of the Moscow central railway ring, at its intersection with the Volokolamsk highway. The plan is made within borders of Moscow circular railway. The development of ring highways system and decentralised city structure have been proposed.

Architect Nikolay Markovnikov, an ideologist of low-rise housing construction, designed and then built a lot of houses for the village Sokol, though there are buildings of other architects as well. All houses in the village (nearly one hundred) have been built on individual projects. They are very diverse in architectural planning and design solutions from one-story, two-story, cottage-type, and from different building materials - log, wooden frame and Sediment, brick, cinder, even from the Armenian tuff. Open plan and a number of interesting methods of street landscaping was implemented there. Residents (mostly artists) showed interest in gardening and landscape design. They planted rare trees, even the plants listed in the Red book. Now the village Sokol covers an area of 21 hectares, each plot has an area of about 9 acres. In postSoviet times, about 30 houses lost their original appearance. Part of them were simply demolished and in their place more modern mansions, which do not represent the historical value, were built (Fig. 11). (Posjolok Sokol, 2004).

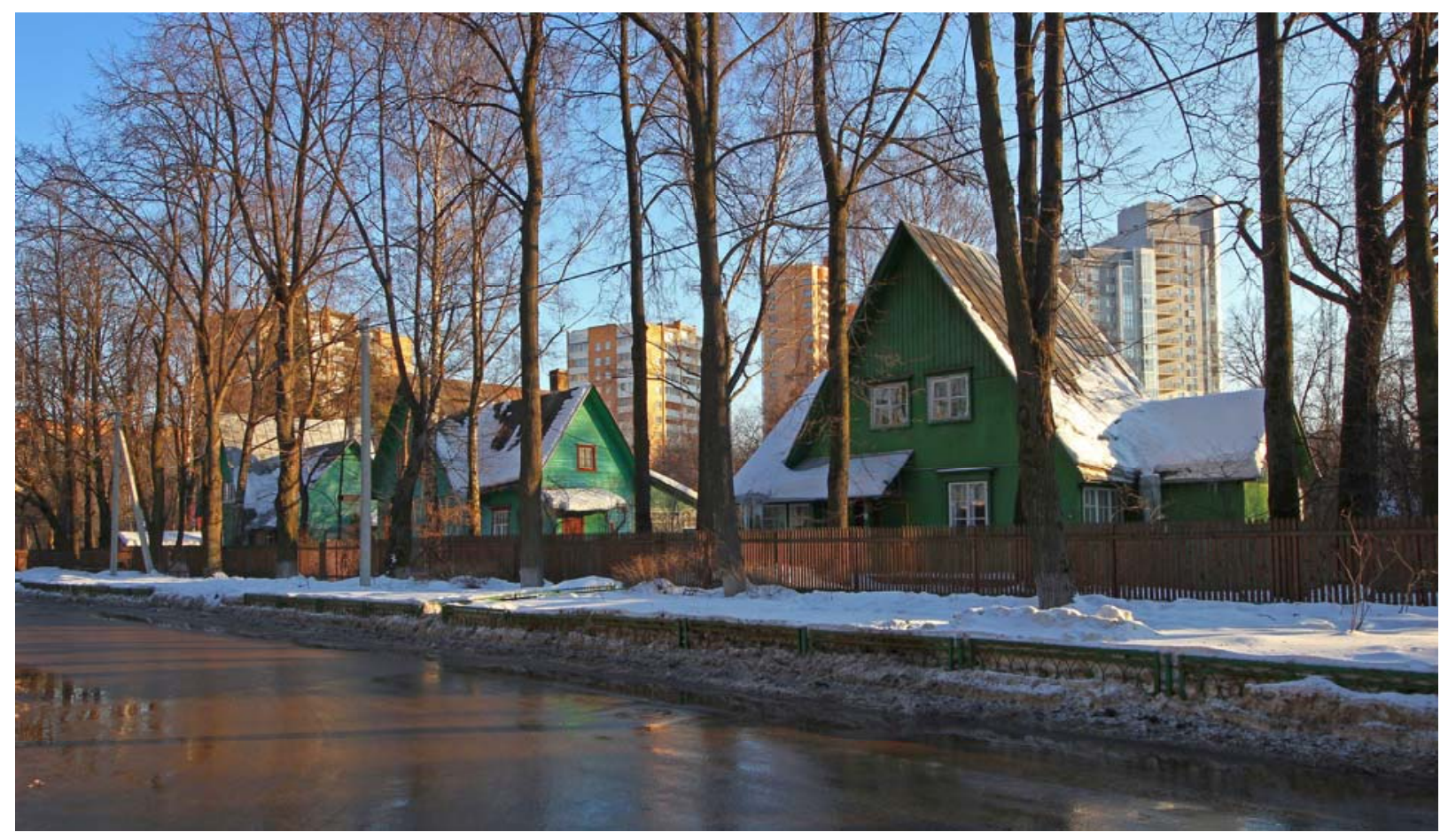

Fig 11. Village Sokol. Photo: A. Savin https://commons.wikimedia.org/w/index.php?curid=14534523

\section{Street and road network}

Closely spaced pereulki (lanes), the distance between them, even in the most central part of the city, within a radius of 500 metres to the north-west of the Kremlin, is the result of the implementation in the XVI-XVII centuries rural planning forms, more precisely, their symbiosis with urban forms. Artisans settled in this part of the city in slododa (large villages) on 
a professional basis. Inside the settlement, houses were close to each other, narrow sides of houses overlooked the street, forming a continuous building front. Behind each house, there was a long garden that was used for "food and fun", and it bordered with the garden of a neighbour whose house overlooked the next street, just densely built up along its front (Gol'denberg, 1935). This method of building was ubiquitous in Moscow in early XVII century (ie, within the modern Garden Ring). Houses in craftsmen villages were built densely by the front along the street or lane, standing house with long narrow gardens behind them, adjacent to the neighbour's garden behind the house that overlooks the neighbouring lane. It is clearly visible on the so-called Sigizmundov plan, drawn up in the 1610s (Fig. 12) This dense routing of lanes in many quarters within the Garden Ring is preserved to these days, having survived multiple changes of the prevailing social strata of the population, functional use of the territory, types and ways of its development. Such events take place now as well.

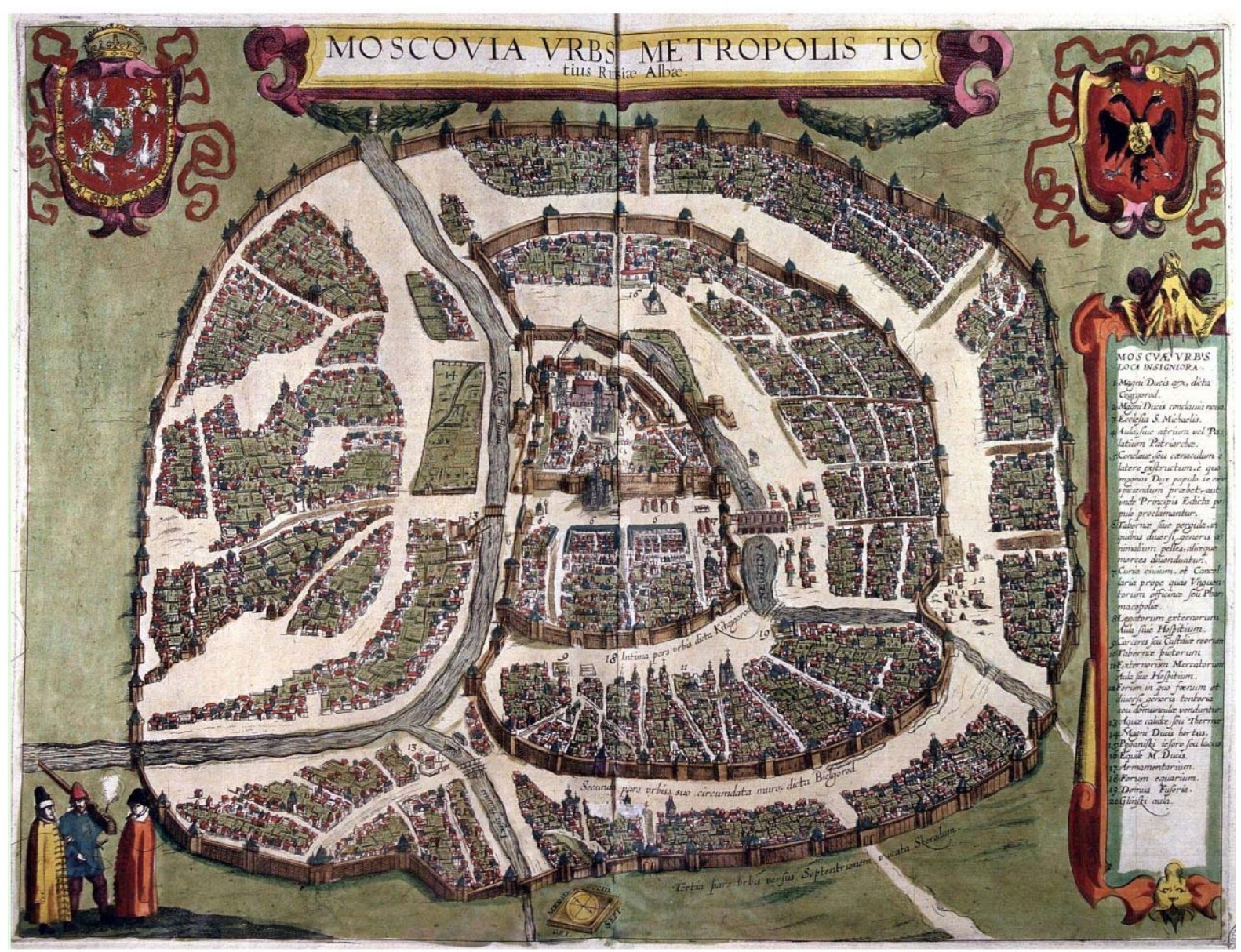

Fig 12. Sigizmundov plan. Source: Savchenko, A., ed. (2013)

\section{Conclusion}

Inclusion of specific rural architectural and planning forms in the urban structure of Moscow is constantly going on for centuries, despite population growth and increasing complexity of economic specialisation. Main drivers of the transformation of its development and planning structure consecutively changed at different stages of urban planning history of the city, from fortification (up to the end of the XVII century) to reconstruction based on the principles of regular planning (XVIII century), to railway construction (XIX century), to reconstruction based on socialist principles, different understandings in different periods of the Soviet Union ( $X X$ century), to post-industrial transformation (XXI century), to in accordance with the changing urban problems preference was done for different rural planning and architectural forms, often transformed significantly compared to the initial prototypes. 
Once included into the structure of the city, rural planning and architectural forms did not disappear, but after the termination of the implementation of their parent species and ways of life really related to agriculture and other "non-urban" activities, they are transformed for integration into urban life and the environment, contributing to an increase in their diversity. This pattern can be traced consistently, at least, from the XVIII century.

The case study of Moscow shows that it is possible to harmoniously form the city "of many speeds" when the islands of the "slow city" are formed and gradually expand within the traditional "fast" global city, represented by different functional types of territories. We examined the features of the diversity of the urban environment from the point of view of including rural architectural and planning forms. In a slow city, in addition to rural forms, there are also purely urban forms - pedestrian zones, city parks and museum areas. The city of quality urban environment is a city of different speeds. In a fast city, there is a place of slow city. Surely, it is inherent not only in Moscow and the tool is the use of including transformed rural architectural forms.

\section{Acknowledgements}

This work was supported by the Russian Foundation for Humanities, project No. 15-03-00740.

Academic references

[1] Brade, I. \& Kovacs, Z. (2014). City and countryside under world-wide urbanization. Regional Research of Russia 4(2), 76-80. DOI: 10.1134/S2079970514020038.

[2] Castells, M. (1996). The rise of the network society. Oxford: Blackwell.

[3] Dewey, R. (1960). The rural-urban continuum: Real but relatively unimportant. American Journal of Sociology, 66(1), 60-66. DOI: 10.1086/222824.

[4] Farrell, T. (2014). The city as a tangled bank. Urban design vs urban evolution. Hoboken: Wiley.

[5] Gol'denberg, P., Gol'denberg, B. (1935). Planirovka zhilogo kvartala Moskvy XVII, XVIII iXIX VV. (Planning residential quarter of Moscow XVII, XVIII and XIX centuries). Moskva/Leningrad: Glavnaja redakcija stroitel'noj literatury.

[6] Howard, E. (1902). Garden cities of tomorrow. London: S. Sonnenschein \& Co., Ltd.

[7] Keough, N. (2005). The sustainable Calgary story: A local response to a global challenge. In Phillips, R., ed., Community indicators measuring systems (pp. 65-95). Aldershot: Ashgate.

[8] Knox, P. (2005). Creating ordinary places: Slow cities in a fast world. Journal of Urban Design 10(1), 1-11. DOI: 10.1080/13574800500062221.

[9] Mayer, H. \& Knox, P. (2009). Pace of life and quality of life: the Slow City Charter. In Sirgy, M. J., Phillips, R. \& Rahtz, D. R., eds., Community quality-of-life indicators: Best cases III (pp. 21-40). Dordrecht: Springer. DOI: 10.1007/978-90-481-2257-8_2.

[10] Niström, L. (1995). The diversity of the urban environment - a result of planning or of laissez-faire? Scandinavian Housing and Planning Research, 12(4), 223-229. DOI: $10.1080 / 02815739508730391$.

[11] Redfield, R. (1930). Tepoztlán, a mexican village: A study of folk life. Chicago: Univ. of Chicago Press.

[12] Ritzer, G. (2004). The McDonaldization of society. Thousand Oaks: Pine Science Press.

[13] Savchenko, A., ed. (2013). Moskva. Preemstvennost' $v$ peremenah. 400 let gradostroitel'nyh planov Moskvy. Moscow: Genplan Institute of Moscow. 
[14] Sorokin, P. \& Zimmerman, C. (1929). Principles of rural-urban sociology. New York: Holt.

[15] Sudjic, D. (1993). The 100 Mile City, London: Harcourt.

[16] Treivish, A. I. (2016). The rural-urban continuum: regional dimensions. In Kotlyakov, V. M., Streleckij, V. N., Glezer, O. B. \& Safronov, S. G., eds., Problemy regional'nogo razvitija Rossii (pp. 51-71). Moscow: Russian Geographical Society.

[17] Ul'janova, G. (2012). Dvorcy, usad'by, dohodnye doma. Istoricheskie rasskazy o nedvizhimosti Moskvy i Podmoskov'ja. Moskva: Forum; Neolit.

Other sources

[18] Cittaslow (2017). Cittaslow, Vereinigung der lebenswerten Stadte in Deutschland. Retrieved January 15, 2017, from http://www.cittaslow.net/.

[19] Posjolok Sokol. Istorija posjolka i ego zhitelej (Sokol Village. The history of the village and its inhabitants) (2004). Moscow: Olma-Press.

[20] Slow cities (2017). Retrieved January 15, 2017, from http://www.create-the-goodlife.com/slow_cities.html.

[21] World Development Report 2009: Reshaping Economic Geography. Washington, DC: The World Bank. 